Ewa Rojews ka ORCID: 0000-0003-3988-810X

Uniwersytet Szczeciński

\title{
Rodzice wobec wychowania seksualnego młodzieży. Raport z badań
}

\section{Parents Towards the Topic of Their Children's Sexual Education. Research Report}

\begin{abstract}
ABSTRAKT
W artykule przyięto tezę, że rodzina stanowi istotne środowisko wychowania seksualnego. Jako takie, może stanowić cenne źródło wsparcia i wiedzy dla dojrzewajqcej młodzieży w kontekście jej seksualności. Pierwsza część tekstu poświęcona została omówieniu tezy mówiq̨cej o rodzinie jako istotnym środowisku wychowania seksualnego.

W dalszej kolejności przedstawione zostały metodologiczne założenia przeprowadzonych badań. Przynoszq one odpowiedź na pytanie: Jaki jest stosunek rodziców wobec wychowania seksualnego ich dzieci? Przyięto następujące szczegółowe problemy badawcze: Jaka jest aktywność wychowawcza rodziców w kontekście seksualności ich dzieci? Jakie trudności zwiqzane $z$ wychowaniem seksualnym dzieci dostrzegaja rodzice? Jakie potrzeby zwiqzane $z$ wychowaniem seksualnym dzieci odczuwaja rodzice? Badania przeprowadzono metodą sondażu diagnostycznego. Wzięło w nich udział 77 rodziców dzieci w wieku 15-18 lat, uczacych się w ostatnich klasach szkół podstawowych oraz szkołach ponadgimnazjalnych z obszaru Gminy i Miasta Szczecin. Wśród ankietowanych rodziców było 66 kobiet i 11 mężczyzn w wieku od 33 do 58 lat.
\end{abstract}

StOWA KLUCZOWE edukacja seksualna, wychowanie w rodzinie, seksualność, rodzina

KEYWORDS

sexual education, education in the family, sexuality, family

SPI Vol. 22, 2019/2

ISSN 2450-5358

e-ISSN 2450-5366

DOI: 10.12775/SPI.2019.2.008

Nadesłano: 23.10.2018

Zaakceptowano: 31.05 .2019

Raporty z badań 
W środkowej części tekstu prezentowane sq uzyskane wyniki badań, opatrzone w podsumowaniu płynq̨cymi z nich wnioskami pedagogicznymi. W odniesieniu do poznania aktywności wychowawczej badanych rodziców, zdecydowana większość z nich realizuje wychowanie seksualne swoich dzieci. Odnotowano również, że badani szeroko rozumiejq proces wychowania seksualnego dostrzegajqc, że wiele sytuacji codziennego życia, takich jak sposób odnoszenia się do siebie rodziców czy wartości pielęgnowane w rodzinie, pozostaje nieobojętne dla wychowania seksualnego ich dzieci. Niemniej jednak tematyka rozmów rodziców z dziećmi ma charakter bardziej instrumentalny niż relacyjny.

Całość artykułu stanowi pedagogicznq refleksie dotyczqca problematyki wychowania seksualnego podejmowanego przez rodziców adolescentów.

\section{ABSTRACT}

In this article it is assumed that the family is an important environment for children's sexual education. Family education can affect the knowledge, behavior and development of adolescents in the area of their sexuality. The first part of this article introduces the thesis, that family is an important environment in determining the sexual behavior of adolescents.

Next, the methodological assumptions of the research are presented. It answers the following question: what is the parental attitude to the sexvality of their children. Subsequently, there specific research problems are presented: what is parental activity in the field of sexual education, what are the difficulties with sexual education, what are the parental needs identified in this area? The research has been carried out by means of a diagnostic survey. The group of respondents comprised 66 women and 11 men, parents of children aged 15-18. The respondents were aged 33-58 and came from Szczecin.

In the middle part of the text, results of scientific research are presented connected with pedagogical proposals. The research results show that most respondents undertake the task of the sexual education of their children. Parents also perceive that many behaviors are causally connected with sexual education, for example - with the quality of relationship in marriage. The character of the conversation about sex between parents and children is rather instrumental than relational. The whole article contains pedagogical reflection on the topic of sexual education in the families of adolescents. 


\section{Wprowadzenie}

Adolescencja jest wyjątkowym czasem w życiu człowieka. Przypada na wiek pomiędzy 10/12 a 20/23 rokiem życia. Stanowi etap przejściowy, umiejscowiony pomiędzy dzieciństwem $\mathrm{z}$ jednej strony i dorosłością z drugiej ${ }^{1}$. Ze względu na niezwykle gwałtowne $\mathrm{i}$ intensywne zmiany występujące w tym okresie, właściwie w każdym obszarze życia młodego człowieka, bywa nazywany czasem burzy i naporu (Sturm and Drang) ${ }^{2}$.

Wielu pedagogów, w tym J. Mastalski, wskazuje, że okres dojrzewania jest czasem szczególnej podatności młodych ludzi na manipulację i przyjmowanie aktualnych mód i trendów, nie zawsze (rzadko) służących ich harmonijnemu rozwojowi. Jak pisze wspomniany autor, „środowisko nastolatków jest jak gąbka nasiąkająca nowościami i ideami proponującymi miraż szczęścia i samorealizacj””3. Młodzież doświadcza naporu wielu niekorzystnych zjawisk i propozycji z ponowoczesnego świata, w którym funkcjonuje. Wśród nich można wymienić choćby supermarketyzację seksu ${ }^{4}$ czy seksualizację ${ }^{5}$.

Dojrzewająca sfera seksualności człowieka wydaje się być szczególnie podatna na wpływ tych zewnętrznych czynników. Jednocześnie jest obszarem ścierania wielu przeciwstawnych impulsów płynących z wnętrza nastolatka. Dla wielu młodych ludzi bywa sferą, w której z różnych przyczyn zdają się oni na własny osąd tego, co jest dla nich dobre, a co może przynieść szkodę lub nie podejmują takich rozważań i przyjmują to, co napływa do nich ze świata zewnętrznego lub co domaga się realizacji z największą w danym momencie siłą.

W niniejszych rozważaniach przyjmuje się tezę, że rodzina stanowi istotne środowisko wychowania seksualnego. Jako takie, może

1 W kwestii początku i zakończenia okresu dojrzewania mogą występować znaczące różnice indywidualne. Por. A. Oleszkowicz, A. Senejko, Dorastanie, w: Psychologia rozwoju człowieka, red. J. Trempała, Warszawa 2001, s. 259.

2 Por. H. Bee, Psychologia rozwoju cztowieka, przeł. A. Wojciechowski, Poznań 2004, s. 326-327.

3 J. Mastalski, Zaniedbane paradygmaty formacyjne nastolatka, „Studia Pedagogica Ignatiana” 2017, t. 20, nr 2, s. 104.

4 Por. T. Szlendak, Supermarketyzacja. Religia i obyczaje seksualne mtodzieży w kulturze popularnej, Wrocław 2008.

5 K. Waszyńska, M. Zielona-Jenek, Zjawisko seksualizacji jako wyzwanie dla wspótczesnej edukacji, „Studia Edukacyjne” 2016, nr 39, s. 351-375. 
stanowić cenne źródło wsparcia i wiedzy dla dojrzewającej młodzieży w kontekście jej seksualności. Prawidłowo funkcjonująca rodzina, panujące $w$ niej relacje i wychowanie seksualne ukierunkowane na wspieranie rozwoju integracji seksualnej mogą być bezpieczną ostoją w okresie burzy i siłą w odparciu tego, co nie służy dojrzewającemu człowiekowi. Ze względu na wagę i aktualność tych zagadnień, przedmiotem zainteresowania w artykule uczyniono rodzinę w kontekście wychowania seksualnego młodzieży. Pierwsza część tekstu poświęcona została omówieniu tezy mówiącej o rodzinie jako istotnym środowisku wychowania seksualnego.

W dalszej kolejności przedstawione zostały metodologiczne założenia przeprowadzonych badań. Przynoszą one odpowiedź na pytanie: Jaki jest stosunek rodziców wobec wychowania seksualnego ich dzieci? Przyjęto następujące szczegółowe problemy badawcze: Jaka jest aktywność wychowawcza rodziców w kontekście seksualności ich dzieci? Jakie trudności związane $\mathrm{z}$ wychowaniem seksualnym dzieci dostrzegają rodzice? Jakie potrzeby związane $\mathrm{z}$ wychowaniem seksualnym dzieci odczuwają rodzice?

W środkowej części tekstu prezentowane są uzyskane wyniki badań, opatrzone $\mathrm{w}$ podsumowaniu płynącymi z nich wnioskami. Całość artykułu stanowi pedagogiczną refleksję dotyczącą problematyki wychowania seksualnego podejmowanego przez rodziców adolescentów.

\section{Rodzina jako istotne środowisko wychowania seksualnego}

Teza mówiąca o tym, że rodzina stanowi istotne środowisko dla rozwoju człowieka nie budzi zastrzeżeń. Została ona wielokrotnie udowodniona, w obszarze dziedziny nauk społecznych w obrębie takich dyscyplin, jak pedagogika, psychologia czy socjologia. Rodzinę w kontekście jej wychowawczego charakteru cechuje między innymi: istnienie długotrwałych i bezpośrednich relacji oraz silnej więzi pomiędzy jej członkami; fakt, że rodzina zaspokaja potrzeby poszczególnych jej członków oraz tworzy i przekazuje wzorce osobowe i identyfikacyjne dla dziecka ${ }^{6}$. Charakter stosunków rodzinnych,

6 B. Kołodziej, Rola rodziny w ksztattowaniu postawy wobec życia jako fundamentalnej wartości, w: Rodzina: źródto życia i szkota mitości, red. D. Kornas-Biela, Lublin 2001, s. 233-234. 
nasyconych miłością i trwających od chwili przyjścia dziecka na świat we wszystkich obszarach i okresach jego życia sprawia, że rodzina jest unikatowym środowiskiem rozwoju osoby.

$\mathrm{Na}$ potrzebę aktywności w obszarze wychowania seksualnego zwraca uwagę wielu specjalistów zajmujących się rozwojem dzieci i młodzieży, tak z obszaru pedagogiki, jak i psychologii i medycyny. Zauważa się jednak istotne różnice w postrzeganiu tego procesu ze względu na przyjmowane cele i środki ich realizacji. W. Półtawska wskazuje dodatkowo, że w ogóle nie jest zasadne mówienie o wychowaniu seksualnym jako takim: „raczej należałoby powiedzieć o potrzebie wypracowania postawy wobec zagadnień seksualnych, gdyż każde wychowanie musi uwzględniać rzeczywistość płci, płciowość stanowi o strukturze osobowości i wszystko, co człowiek czyni, nosi znamiona jego płci"7. Przytoczone stanowisko wydaje się dziś być odosobnionym. Akcentuje jednak istotną z wychowawczego punktu widzenia tezę, że seksualność człowieka jest wymiarem jego egzystencji i jako taka nie może zostać zmarginalizowana czy niedostrzeżona jako istotna w rozwoju człowieka.

Wobec pluralizmu stanowisk w obrębie wychowania seksualnego, kluczowe jest przedstawienie prezentowanej koncepcji seksualności. Ona bowiem pociąga za sobą określony sposób rozumienia wychowania seksualnego. W niniejszej pracy przyjmuje się, że:

Seksualność jest podstawowym elementem bycia człowiekiem przez całe życie, obejmującym seks, płciową identyfikację i role, orientację seksualną, erotyzm, pożądanie, intymność i reprodukcję. Seksualność jest doświadczana i wyrażana w myślach, fantazjach, przeżyciach, przekonaniach, wartościach, zachowaniach, rolach i związkach. Seksualność powstaje na skutek interakcji czynników biologicznych, psychologicznych, społecznych, ekonomicznych, politycznych, kulturowych, etycznych, prawnych, historycznych, religijnych i duchowych ${ }^{8}$.

Jest to integralne rozumienie seksualności, jako wymiaru funkcjonowania człowieka. Tak postrzegana seksualność jest nierozerwalnie związana ze wszystkimi innymi obszarami ludzkiej egzystencji

7 W. Póltawska, Rola rodziców w wychowaniu seksualnym mtodzieży, w: Wychowanie w rodzinie, red. F. Adamski, Kraków 2010, s. 193.

8 M. Laphimon, A Glossary of Term In Gender and Sexuality, Seul 2005, za: Z. Lew-Starowicz, Seksuologia psychospoteczna, w: Podstawy seksuologii, red. Z. Lew-Starowicz, V. Skrzypulec, Warszawa 2010, s. 25. 
i w nie wszystkie jest zaangażowana. Można tu mówić o podwójnym powiązaniu. Seksualność przenika każdy obszar ludzkiej egzystencji, bowiem człowiek zawsze działa jako istota seksualna, nigdy zaś w oderwaniu od swojej seksualności. Z drugiej zaś strony wielowymiarowa natura seksualności sprawia, że każdy obszar życia człowieka - fizyczność, sfera psychiczna, emocjonalność, moralność, duchowość - w określony sposób jest w nią zaangażowany. Taka koncepcja seksualności wydaje się zgodna $\mathrm{z}$ personalistycznym przekonaniem o niepodzielności i integralności osoby ludzkiej, a związane $z$ nią wysiłki wychowawcze zgodne są z duchem pedagogiki integralnej, dla której człowiek jest „istotą niepodzielną, nierozdartą na szereg osobnych cząstek"

W konsekwencji tak holistycznie rozumianej ludzkiej seksualności przyjmuje się, że wychowanie seksualne stanowi proces, którego celem jest osiągnięcie integracji seksualnej. Integracja seksualna stanowi zaś

(...) wynik procesu harmonizowania wszystkich wymiarów życia osoby związanych $\mathrm{z}$ seksualnością. Fundamentem integracji seksualnej jest uznanie złożonej, wielowymiarowej istoty seksualności powiązanej z całym życiem człowieka. Integralna wizja seksualności polega na uznaniu, że seksualność stanowi jeden z wymiarów życia osoby i jako taka nie stanowi wartości autonomicznej. Integracja seksualna jest wynikiem prowadzenia świadomego procesu samowychowania zmierzającego do scalenia wszystkich wymiarów osobowości człowieka związanych z seksualnością według właściwej im hierarchii. Integracja seksualna objawia się $\mathrm{w}$ uwzględnianiu $\mathrm{w}$ działaniu wszystkich wymiarów seksualności: biologicznego, psychicznego, emocjonalnego, społecznego oraz moralnego. Na integrację seksualną składają się: posiadanie pozytywnej i integralnej wizji seksualności człowieka, akceptacja tożsamości płciowej i związanych z nią ról, dojrzałość biologiczna, dojrzałość emocjonalnego wymiaru seksualności, jej psychizacja oraz humanizacja ${ }^{10}$.

Tak rozumiane wychowanie seksualne jest procesem długofalowym i trwa całe życie. Obejmuje działania tak intencjonalne, jak i nieintencjonalne. Ostatecznie zaś powinno zmierzać do przejęcia

9 L. Górska, Podmiot i podmiotowośc w wychowaniu. Studium w perspektywie poznawczej pedagogiki integralnej, Szczecin 2008, s. 28.

10 E. Rojewska, Personalistyczna orientacja wychowawcza rodziców a integracja seksualna mtodzieży. Badania empiryczne, niepublikowana rozprawa doktorska napisana pod kierunkiem prof. dra hab. Zdzisława Kroplewskiego, Szczecin 2015, s. 119-120. 
odpowiedzialności za rozwój integracji przez samą osobę, czyli do podjęcia samowychowania seksualnego.

W takim szerokim ujęciu procesu wychowania seksualnego szczególnie miejsce zajmuje rodzina. Pierwsze uzasadnienie tej tezy jest dość pragmatyczne. Jak pisze A. Mazan, dojrzewanie dziecka trwa około 25 lat. W tym długim okresie jedynie rodzina jest nieustannie obecna przy dziecku, pozostałe instytucje wychowawcze podejmują działania raczej wyspowe, choć niejednokrotnie intensywne, nastawione na zaspokojenie różnych potrzeb rozwojowych wychowanka ${ }^{11}$. Istotnymi cechami rodziny w tym kontekście, wskazującymi na jej znaczenie $\mathrm{w}$ wychowaniu seksualnym, są naturalność i ciągłość procesu wychowania ${ }^{12}$.

I. Obuchowska i A. Jaczewski wskazują na trzy istotne role środowiska rodzinnego w wychowaniu seksualnym dziecka. Pierwsza rola związana jest $\mathrm{z}$ faktem, że $\mathrm{w}$ okresie dzieciństwa kształtowane są przez rodziców takie właściwości psychiczne dziecka, które rzutują na jego późniejsze postawy wobec seksualności. Autorzy zaliczają do tych właściwości otwartość na świat i ukierunkowanie moralne. Otwartość na świat rozumie się jako postawę poszukującą, którą przejawia osoba kreatywna w wyborze i tworzeniu wzorów i wartości. Tak rozumiana otwartość na świat ma stanowić przeciwwagę dla konformizmu. W przypadku ukierunkowania moralnego istotne jest, aby dzieci przeszły drogę od zewnętrznego kierowania ich zachowaniem do wewnątrzsterownego postępowania. Dokonuje się to na drodze wytwarzania określonej, stałej orientacji moralnej związanej z fundamentalnymi wartościami życiowymi. I. Obuchowska i A. Jaczewski wskazują, że „wczesna orientacja moralna, którą dziecko wynosi z domu rodzinnego, stanowi punkt odniesienia w nowych, trudnych sytuacjach, w jakich młodzi ludzie muszą podejmować samodzielne decyzje natury moralnej"13. Druga rola rodziców w kontekście wychowania seksualnego dotyczy kształtowania

11 A. Mazan, Metody integracji w wychowaniu rodzinnym, w: Rodzina przestrzeniq rozwoju osoby. Perspektywa pedagogiczna, red. M. Jeziorański, D. Opozda, A. Rynio, Lublin 2012, s. 131.

12 E. Jundziłl, Środowiskowe uwarunkowania ksztattowania sie postaw mtodzieży wobec seksu, w: Mitość i seks w percepcji uczniów, red. R. Pawłowska, E. Jundziłł, Koszalin 1999, s. 106.

13 I. Obuchowska, A. Jaczewski, Rozwój erotyczny, Warszawa 2002, s. 57. 
u dzieci umiejętności komunikowania uczuć, trzecia zaś przejawia się w dostarczanych przez rodziców wzorach pełnienia ról społecznych związanych z płcią ${ }^{14}$.

Rodzina zatem, jak żadne inne środowisko, jest miejscem kształtowania się identyfikacji płciowej. Ta, rozumiana jako akceptowane poczucie przynależności do własnej płci i realizowanie określonej roli płciowej, odbywa się od pierwszych lat życia w rodzinie za sprawą więzi uczuciowej pomiędzy rodzicami a dzieckiem, naśladowania rodzica tej samej płci, kształtowania obrazu własnej płci i zróżnicowanego sposobu wychowania w rodzinie dziewczynek i chłopców ${ }^{15}$. W procesie identyfikacji płciowej ważny jest nie tylko prawidłowy kontakt rodzica $\mathrm{z}$ dzieckiem tej samej płci, ale z obojgiem rodziców. Dzięki pozytywnym relacjom $\mathrm{z}$ rodzicem tej samej płci, dziecko zyskuje model osobowościowy oraz model pełnienia płciowej roli społecznej. Gdy rodzice przejawiają względem siebie postawę akceptacji, rola ta zostaje istotnie wzmocniona. Jeśli brakuje w rodzinie prawidłowych relacji pomiędzy rodzicami w tym względzie, proces identyfikacji płciowej dziecka może przebiegać nieprawidłowo ${ }^{16}$.

Istotne znaczenie w wychowaniu seksualnym w rodzinie ma również proces naśladownictwa. Wzór osobowy rodzica, jako pierwszy i ten, z którym dziecko jest silnie związane emocjonalnie, staje się podstawą przyszłych przekonań i zachowań dotyczących seksualności. Zdaniem E. Jundziłł, „każde zachowanie rodziców, wiążące się $\mathrm{w}$ najmniejszym stopniu ze sprawami seksu, dostarcza wzoru postępowania"17. Obserwując rodziców, dziecko uczy się wyrażania emocji, ról płciowych, komunikacji, rozwiązywania konfliktów, stosunku do cielesności, bliskości między poszczególnymi członkami rodziny, przyjmuje kultywowane w rodzinie wartości. Jak wskazuje pedagog i terapeuta rodzinny J. Juul, życie dorosłych ma większy

14 Por. I. Obuchowska, A. Jaczewski, Rozwój erotyczny, dz. cyt., s. 56-63. Niedostatki w zakresie realizacji tych ról przez rodzinę mają swoje konsekwencje dla jakości dorosłego życia człowieka, także w kontekście jego seksualności. Tamże.

15 Por. Z. Lew-Starowicz, Seksuologia sqdowa, Warszawa 2000, s. 93.

16 Tamże.

17 E. Jundzilł, Środowiskowe uwarunkowania ksztattowania siępostaw mtodzieży wobec seksu, w: Mitość i seks w percepcji uczniów, dz. cyt. s. 106. 
wpływ na dzieci niż jakiekolwiek próby i metody wychowawcze ${ }^{18}$. Takie ujęcie pociąga za sobą szczególną odpowiedzialność rodziców za rozwój seksualny ich dzieci. Życiowe wybory i postawy rodziców są kluczowym elementem wychowania seksualnego w rodzinie.

Rodzina jest miejscem doświadczania wyjątkowo silnych więzów i zaspokajania fundamentalnych osobowych potrzeb. Należą do nich potrzeba miłości, bezpieczeństwa i akceptacji. Od jakości zaspokojenia tych potrzeb i jakości więzi pomiędzy rodzicami a dzieckiem zależy $\mathrm{w}$ znacznej mierze jego dalszy rozwój, także seksualny ${ }^{19}$. E. Jundziłł dowodzi, że zaspokojona w środowisku rodzinnym potrzeba kontaktu emocjonalnego dziecka $\mathrm{z}$ rodzicami koreluje $\mathrm{z}$ jego późniejszą dojrzałością w aspekcie seksualnym. Decyzje związane z doświadczaniem seksualności mają wówczas właściwą podbudowę, w przypadku zaś braku zaspokojenia potrzeby kontaktu emocjonalnego w okresie dzieciństwa i dorastania, podejmowana aktywność seksualna może mieć na celu kompensowanie braków uczuciowych ${ }^{20}$. W przypadku tak fundamentalnych potrzeb dzieci i młodzieży, jak miłości, akceptacji, bezpieczeństwa, kontaktu emocjonalnego, więzi, rola rodziny jest niezastępowalna, a zakłócenia w realizacji tych potrzeb mogą prowadzić do zaburzeń procesu integracji seksualnej. Przykładem zaburzenia w tym zakresie jest wczesna inicjacja seksualna młodzieży, która koreluje z czynnikami rodzinnymi, takimi jak rozwód rodziców, ich nieudane małżeństwo, brak ojca w rodzinie, patologia rodziny ${ }^{21}$, brak silnej więzi matki z córką, pracoholizm rodziców czy samotność 22 .

W powyższych rozważaniach akcent położony został na jakość relacji wewnątrzrodzinnych. Obok nich, ważnym elementem wychowania seksualnego w rodzinie są rozmowy dotyczące explicite seksualności pomiędzy rodzicami a dziećmi. Treść, sposób i okoliczności

J. Juul, Twoja kompetentna rodzina, przeł. D. Syska, Podkowa Leśna 2007.

19 M. Ryś, Poziom zaspokojenia potrzeb w dzieciństwie a zaspokojenie potrzeb w matżeństwie, „Problemy Rodziny” 1993, nr 1, s. 20-21.

20 E. Jundzilł, Rola prawidtowo zaspokojonej potrzeby mitości w życiu dorostego cztowieka, w: Mitość i seks w percepcji uczniów, red. R. Pawłowska, E. Jundziłł, Koszalin 1999, s. 39. 
ich prowadzenia powinny być uwarunkowane potrzebami dziecka i możliwościami przyjęcia określonych informacji. W praktyce wychowania seksualnego $\mathrm{w}$ rodzinie są one również uwarunkowane postawami rodziców w tym aspekcie (ich wiedzą, nastawieniem emocjonalnym oraz podejmowanymi w tym zakresie działaniami). Jak wykazuje wiele badań naukowych, dzieci w znacznej mierze oczekują takich rozmów z rodzicami, chcą, by były one prowadzone w sposób kompetentny merytorycznie i metodycznie. Respondenci biorący udział badaniach prowadzonych przez J. Kurzępę wskazywali, że kompetentny rodzic w tym zakresie to taki, który buduje atmosferę zaufania, kompetencji i rzetelności. Ważne dla badanych było również to, aby rodzice uwalniali ich od poczucia wstydu i obawy przed kompromitacją. Młodzież oczekuje od rodziców podejmujących rozmowy o seksualności wysokiego poziomu empatii, asertywności, dużej wiedzy merytorycznej, poprawnego języka i nieuchylania się od nawet najtrudniejszych pytań ${ }^{23}$.

Rozmowy dotyczące sfery seksualnej, ze względu na jej intymny charakter, choć często dotyczą kwestii instrumentalnych, nie powinny mieć instrumentalnego charakteru. Potrzeba w tym względzie otwartości rodziców i dzieci na siebie nawzajem, wzajemnego poszanowania i uznania odrębności. Rozmowy dotyczące seksualności powinny być elementem osobowego dialogu rodzica i dziecka ${ }^{24}$.

Podsumowując można przyjąć, że znaczenie rodziny dla kształtowania się integracji seksualnej młodzieży, jest holistyczne. Dostrzega się tu dwa aspekty. Z jednej strony potencjalnie każdy aspekt życia rodziny ma znaczenie dla rozwoju (lub braku rozwoju) integracji seksualnej dziecka. Zgodne jest to ze stanowiskiem Z. Lwa-Starowicza, który twierdzi, że w tworzeniu się wzorców postaw wobec szeroko rozumianej seksualności, a więc między innymi seksu, płci, relacji z parterami i związków, ma udział cały proces wychowania w rodzinie, wszystkie jego aspekty ${ }^{25} . Z$ drugiej zaś strony, holizm znaczenia rodziny dla wychowania seksualnego wyraża się w tym, że rodzina oddziałuje na wszystkie aspekty życia wychowanka, wszystkie wymiary

23 Por.J. Kurzępa, Zagrożona niewinnośc. Zaktócenia rozwoju seksualności wspótczesnej mtodzieży, Kraków 2007, s. 184.

24 Por. W. Bołoz, Promocja osoby w rodzinie, Warszawa 1998, s. 173.

25 Por. Z. Lew-Starowicz, Seks partnerski, Warszawa 1983, s. 9. 
jego egzystencji, także w kontekście seksualności - biologiczny, psychiczny, emocjonalny, społeczny i moralny. Ma ona możliwość kształtowania postaw wobec samego siebie i innych ludzi, sposobów myślenia, przekazywania określonych wartości, przekazywania wiedzy i wyjaśnień o otaczającym świecie.

Przyjęcie konstatacji, że wychowanie seksualne w rodzinie ma charakter holistyczny niesie z sobą wiele wyzwań. W pierwszej kolejności dotyczą one rodziców. Fundamentalna wydaje się tu świadomość, że rodzice mają przemożny wpływ na rozwój seksualny swoich dzieci. Jak bowiem wskazano, atmosfera w domu, sposób odnoszenia się rodziców do siebie i do dzieci, treść i sposób prowadzonych rozmów, sposoby realizacji ról płciowych - wszystko to nie jest obojętne w procesie wychowania seksualnego. Należy jednak zaznaczyć, że wpływ środowiska rodzinnego na rozwój integracji seksualnej młodzieży nie ma charakteru determinującego. Osoby wychowujące się w rodzinach, które nie stwarzają optymalnych okoliczności rozwoju, mogą osiągnąć integrację seksualną, choć proces dochodzenia do niej będzie trudniejszy niż w przypadku dzieci doświadczających prawidłowych wzorców rodzinnych. Ponadto oczekuje się, że rodzice będą kompetentnymi przewodnikami po niezwykle złożonym i wymagającym najwyższej wrażliwości świecie rozwijającej się seksualności dziecka. Sprostanie temu zadaniu wydaje się wymagać od rodziców nie tylko dojrzałości osobowościowej, ale również niekiedy wsparcia metodycznego, np. w formie warsztatów prowadzonych w szkole przez pedagoga.

Przyjęcie holistycznego charakteru wychowania w rodzinie niesie z sobą wyzwania nie tylko dla rodziców, ale i dla profesjonalnych badaczy tego zjawiska. Obejmuje ono bowiem wiele zróżnicowanych zagadnień, dotyczy i dzieci, i młodzieży, i dorosłych oraz wszystkich sfer życia człowieka. Przyjęcie takiej koncepcji seksualności, a w konsekwencji wychowania seksualnego, prowadzi do konieczności integrowania wiedzy $\mathrm{z}$ różnych dyscyplin badając ten właśnie obszar funkcjonowania rodziny i poszczególnych jej członków. R. Włodarczyk i W. Żłobicki wskazując na inter- i transdyscyplinarny charakter pedagogiki twierdzą, że „bez przekraczania własnych granic, obligatoryjnego korzystania z dorobku filozofii, psychologii, socjologii, antropologii czy nauk politycznych, [pedagogika - przyp. E.R.] bywa bezsilna jako instrument opisu, rozumienia czy narzędzie 
przygotowujące do działania”26. Dotyczy to również pedagogiki rodziny. Z. Tyszka określając przedmiot pedagogiki rodziny - rodzinę, pisze o niej jako interdyscyplinarnym i multidyscyplinarnym przedmiocie badań ${ }^{27}$. Taki stan rzeczy wymaga od badaczy szczególnej ostrożności, wnikliwości i kompetencji w prowadzonych analizach.

\section{Metodologia badań własnych}

Przedmiotem badań uczyniono stosunek rodziców wobec wychowania seksualnego ich dzieci. Główny cel badań stanowi rozpoznanie stosunku rodziców wobec wychowania seksualnego ich dzieci. Szczegółowe cele badawcze to poznanie aktywności wychowawczej rodziców w kontekście seksualności ich dzieci, rozpoznanie trudności doświadczanych przez rodziców w kontekście wychowania seksualnego ich dzieci oraz rozpoznanie potrzeb związanych z wychowaniem seksualnym dzieci. Założony cel nadał badaniu charakter diagnostyczny.

Główny problem badawczy przyjął postać pytania: Jaki jest stosunek rodziców wobec wychowania seksualnego ich dzieci? Przyjęto następujące szczegółowe problemy badawcze: Jaka jest aktywność wychowawcza rodziców w kontekście seksualności ich dzieci? Jakie trudności związane $\mathrm{z}$ wychowaniem seksualnym dzieci dostrzegają rodzice? Jakie potrzeby związane $\mathrm{z}$ wychowaniem seksualnym dzieci odczuwają rodzice?

$\mathrm{Na}$ potrzeby niniejszego artykułu przeprowadzone zostały badania empiryczne metodą sondażu diagnostycznego. Wykorzystano technikę ankietowania, zaś narzędzie badawcze stanowił autorski kwestionariusz ankiety. W badaniu wzięło udział $77^{28}$ rodziców dzieci w wieku 15-18 lat, uczących się w ostatnich klasach szkół podstawowych oraz szkołach ponadgimnazjalnych z obszaru Gminy

26 R. Włodarczyk, W. Żłobicki, Wstęp, w: Interdyscyplinarnośc i transdyscyplinarność pedagogiki - wymiary teoretyczny i praktyczny, red. R. Włodarczyk, W. Żłobicki, Kraków 2011, s. 9.

27 Z. Tyszka, Socjologia rodziny a pedagogika rodziny. Przedmiot badań - możliwości wspótdziatania badawczego, „Roczniki Socjologii Rodziny” 1998, t. 10, s. 77.

28 W pojedynczych przypadkach rodzice nie udzielili odpowiedzi na pytanie $\mathrm{w}$ ankiecie. Zostało to uwzględnione w obliczeniach statystycznych, dlatego niekiedy liczba $\mathrm{N}$ jest mniejsza niż 77 . 
i Miasta Szczecin. Wśród ankietowanych rodziców było 66 kobiet oraz 11 mężczyzn w wieku od 33 do 58 lat $(M=43,64 ; S D=5,84)$. Dominowały osoby o wykształceniu wyższym (80,1\%), następnie średnim (17,6\%), jedna osoba zakończyła edukację na poziomie podstawowym. Badanie przeprowadzono we wrześniu 2018 roku.

Analiza statystyczna została przeprowadzona w pakiecie IBM SPSS Statistics V25. Wykorzystano techniki opisu statystycznego oraz test chi-kwadrat Pearsona do weryfikacji zależności pomiędzy danymi o nominalnym i porządkowym poziomie organizacji. Za wskaźnik pełnej istotności statystycznej przyjęto wartość $\mathrm{p}<0,05$, zaś wartość $\mathrm{p}<0,1$ przyjęto za wskaźnik nie $\mathrm{w}$ pełni istotnej tendencji statystycznej.

Ze względu na niewielką grupę respondentów, w szczególności mężczyzn, uzyskane wyniki mają charakter sygnalny i przyczynkowy, odnoszone są wyłącznie do badanych osób, nie zaś do całej populacji. Niemniej ze względu na szczególną trudność w uzyskaniu zgody rodziców adolescentów na udział w badaniach dotyczących seksualności oraz fakt, że istnieje niewiele tego typu aktualnych analiz, uznano za celowe, $z$ powyższym zastrzeżeniem, przedstawienie uzyskanych wyników i płynących z nich wniosków.

\section{Aktywność wychowawcza rodziców w kontekście seksualności młodzieży}

Zdecydowana większość respondentów $(71,1 \%)$ zadeklarowała, że podejmuje wychowanie seksualne swoich dzieci w środowisku rodzinnym. Przeciwnej odpowiedzi udzieliło jedynie 6,6\% badanych. Co interesujące, ponad jedna piąta rodziców wskazała, że trudno jej określić, czy taką aktywność podejmuje. Dane te zostały przedstawione $\mathrm{w}$ tabeli 1 . Być może ten stan rzeczy związany jest $\mathrm{z}$ trudnością jednoznacznego określenia przez rodziców, poprzez jaką ich aktywność dokonuje się wychowanie seksualne. 
Tabela 1. Podejmowanie przez rodziców wychowania seksualnego w środowisku rodzinnym

\begin{tabular}{|l|c|c|c|c|c|c|}
\hline \multirow{2}{*}{$\begin{array}{l}\text { Podejmowane wychowania } \\
\text { seksualnego swoich dzieci } \\
\text { w środowisku rodzinnym }\end{array}$} & \multicolumn{2}{|c|}{ Cała grupa, $\mathbf{n = 7 7}$} & \multicolumn{2}{|c|}{ Kobiety, n=66 } & \multicolumn{2}{c|}{ Mężczyźni, n=1 1 } \\
\cline { 2 - 7 } & $\mathbf{N}$ & $\%$ & $\mathbf{N}$ & $\%$ & $\mathbf{N}$ & $\%$ \\
\hline Tak & 54 & 71,1 & 45 & 69,2 & 9 & 81,8 \\
\hline Nie & 5 & 6,6 & 4 & 6,2 & 1 & 9,1 \\
\hline Trudno powiedzieć & 17 & 22,4 & 16 & 24,6 & 1 & 9,1 \\
\hline
\end{tabular}

Źródło: badania własne.

Wśród respondentów dominowało szerokie rozumienie procesu wychowania seksualnego, zgodnie z którym niemal każde zachowanie rodziców pozostaje $\mathrm{z}$ nim $\mathrm{w}$ związku. Choć różnice $\mathrm{w}$ odpowiedziach rodziców były nieznaczne i w odniesieniu do przedstawionych $\mathrm{w}$ ankiecie sytuacji o wszystkich badani wypowiedzieli się, że zdecydowanie lub raczej mają one związek $\mathrm{z}$ wychowaniem seksualnym $w$ rodzinie, to jednak najsilniej rodzice byli przekonani o tym, że to bezpośrednie rozmowy z dzieckiem o seksualności (średnia 4,49) oraz przekazywanie informacji związanych z seksualnością, np. o miesiączkowaniu czy chorobach przenoszonych drogą płciową (średnia 4,48) są elementami wychowania seksualnego. Zbliżone nasilenie dotyczyło przekonania o tym, że pielęgnowanie wartości (średnia 4,43) i sposób odnoszenia się rodziców do siebie (średnia $4,37)$ są elementami wychowania seksualnego w rodzinie. Nie odnotowano $\mathrm{w}$ tym zakresie istotnych statystycznie różnic pomiędzy wypowiedziami kobiet i mężczyzn. Dane te przedstawiono w tabeli 2 . 
Tabela 2. Przekonanie rodziców o tym, które zachowania i sytuacje sq elementami wychowania seksualnego $w$ rodzinie

\begin{tabular}{|c|c|c|c|c|c|c|c|c|c|c|c|}
\hline \multirow{2}{*}{$\begin{array}{l}\text { Przekonanie rodzi- } \\
\text { ców o tym, które } \\
\text { zachowania i sytu- } \\
\text { acje sq elementami } \\
\text { wychowania seksual- } \\
\text { nego w rodzinie }\end{array}$} & \multicolumn{2}{|c|}{$\begin{array}{l}\text { Zdecydo- } \\
\text { wanie tak }\end{array}$} & \multicolumn{2}{|c|}{ Raczej tak } & \multicolumn{2}{|c|}{$\begin{array}{l}\text { Trudno po- } \\
\text { wiedzieć }\end{array}$} & \multicolumn{2}{|c|}{ Raczej nie } & \multicolumn{2}{|c|}{$\begin{array}{l}\text { Zdecydo- } \\
\text { wanie nie }\end{array}$} & \multirow[t]{2}{*}{$\begin{array}{l}\text { Średnia } \\
\text { (od } 1 \text { do 5) }\end{array}$} \\
\hline & $\mathbf{N}$ & $\%$ & $\mathbf{N}$ & $\%$ & $\mathbf{N}$ & $\%$ & $\mathbf{N}$ & $\%$ & $\mathbf{N}$ & $\%$ & \\
\hline $\begin{array}{l}\text { Życzliwa atmosfera } \\
\text { w domu }\end{array}$ & 37 & 50 & 22 & 29,7 & 9 & 12,2 & 3 & 4,1 & 3 & 4,1 & 4,18 \\
\hline $\begin{array}{l}\text { Bezpośrednie roz- } \\
\text { mowy z dzieckiem } \\
\text { o seksualności }\end{array}$ & 49 & 64,5 & 20 & 26,3 & 4 & 5,3 & 1 & 1,3 & 2 & 2,6 & 4,49 \\
\hline $\begin{array}{l}\text { Wartości pielęgnowa- } \\
\text { ne w rodzinie }\end{array}$ & 43 & 58,1 & 24 & 32,4 & 5 & 6,8 & 0 & 0 & 2 & 2,7 & 4,43 \\
\hline $\begin{array}{l}\text { Przekazywanie infor- } \\
\text { macji zw. z seksualnoś- } \\
\text { ciq, seksem (np. o mie- } \\
\text { siqczce czy chorobach } \\
\text { przenoszonych droga } \\
\text { płciowq) }\end{array}$ & 49 & 65,3 & 18 & 24,0 & 5 & 6,7 & 1 & 1,3 & 2 & 2,7 & 4,48 \\
\hline $\begin{array}{l}\text { Sposób realizowania } \\
\text { kobiecości/męskości } \\
\text { przez mamę/tatę }\end{array}$ & 33 & 45,2 & 25 & 34,2 & 10 & 13,7 & 3 & 4,1 & 2 & 2,7 & 4,15 \\
\hline $\begin{array}{l}\text { Sposób odnoszenia się } \\
\text { do siebie rodziców }\end{array}$ & 46 & 61,3 & 18 & 24,0 & 6 & 8,0 & 3 & 4,0 & 2 & 2,7 & 4,37 \\
\hline $\begin{array}{l}\text { Sposób odnoszenia się } \\
\text { rodziców do dzieci }\end{array}$ & 38 & 51,4 & 24 & 32,4 & 6 & 8,1 & 2 & 2,7 & 4 & 5,4 & 4,22 \\
\hline $\begin{array}{l}\text { Rozmawianie o emo- } \\
\text { cjach w rodzinie } \mathrm{i} \text { ich } \\
\text { okazywanie }\end{array}$ & 39 & 52,0 & 24 & 32,0 & 8 & 10,7 & 1 & 1,3 & 3 & 4,0 & 4,27 \\
\hline $\begin{array}{l}\text { Dbałość o zdrowie (np. } \\
\text { wizyty w ginekologa } \\
\text { mamy) }\end{array}$ & 35 & 48,6 & 21 & 29,2 & 12 & 16,7 & 1 & 1,4 & 3 & 4,2 & 4,17 \\
\hline $\begin{array}{l}\text { Troszczenie się o bli- } \\
\text { skie relacje między } \\
\text { członkami rodziny (np. } \\
\text { wspólne spędzanie } \\
\text { czasu) }\end{array}$ & 34 & 45,9 & 22 & 29,7 & 11 & 14,9 & 5 & 6,8 & 2 & 2,7 & 4,09 \\
\hline
\end{tabular}

Źródło: badania własne. 
Badani rodzice w zdecydowanej większości doceniali istotną rolę rodziny w wychowaniu seksualnym młodzieży (92,2\% respondentów), niezależnie od ich płci. Ponadto zauważono istotną statystycznie zależność pomiędzy przekonaniem o tym znaczeniu a podejmowaniem wychowania seksualnego w rodzinie. Dane te przedstawiono $\mathrm{w}$ tabeli 3. Wydaje się uzasadnione z psychologicznego punktu widzenia, że im silniej człowiek jest przekonany do określonej idei $\mathrm{w}$ tym przypadku do istotnego znaczenia rodziny w wychowaniu seksualnym młodzieży, tym chętniej wciela ją w życie - istotnie podejmuje określone działania będące wyrazem wychowania seksualnego. Fakt, że rodzice dostrzegają istotną rolę środowiska rodzinnego dla procesu wychowania budzi uznanie. Może to stanowić bazę dla wspierania realizacji tego procesu, a nie dopiero jego inicjowania.

Tabela 3. Zależność pomiędzy przekonaniem rodziców o znaczeniu rodziny w wychowaniu seksualnym a jego podejmowaniem

\begin{tabular}{|l|c|c|c|c|c|c|}
\hline \multirow{2}{*}{$\begin{array}{l}\text { Znaczenie rodziny } \\
\text { w wychowaniu seksualnym } \\
\text { młodzieży }\end{array}$} & \multicolumn{6}{c|}{$\begin{array}{c}\text { Podejmowanie wychowania seksualnego swojego dziecka } \\
\text { w środowisku rodzinnym }\end{array}$} \\
\cline { 2 - 7 } & \multicolumn{2}{|c|}{ TAK } & \multicolumn{2}{c|}{ NIE } & \multicolumn{2}{c|}{ Trudno powiedzieć } \\
\cline { 2 - 7 } & N & $\%$ & N & $\%$ & N & $\%$ \\
\hline Zdecydowanie ważne & 37 & 69,8 & 0 & 0 & 8 & 47,1 \\
\hline Ważne & 13 & 24,5 & 3 & 60,0 & 8 & 47,1 \\
\hline Trudno powiedzieć & 2 & 3,8 & 0 & 0 & 1 & 5,9 \\
\hline Raczej nieważne & 0 & 0 & 0 & 0 & 0 & 0 \\
\hline Zdecydowanie nieważne & 1 & 1,9 & 2 & 40,0 & 0 & 0 \\
\hline
\end{tabular}

$X^{2}=25,508 ; d f=6 ; p<0,001$

Źródło: badania własne.

Wśród osób biorących udział w badaniu, poczucie kompetencji rodziców w kwestii wychowania seksualnego można określić jako umiarkowane (średnia 3,79). Nie odnotowano w tym względnie różnic pomiędzy kobietami a mężczyznami, zauważono jednak istotną statystycznie zależność: im wyższe jest poczucie kompetencji badanych rodziców w kwestii wychowania seksualnego, tym częściej 
realizują je oni w rodzinie (te dane przedstawiono w tabeli 4). Jest to wynik zrozumiały $\mathrm{z}$ psychologicznego punktu widzenia, ma on także wydźwięk pedagogiczny. Przyjmując istotną rolę rodziny w wychowaniu seksualnym, warto zwrócić uwagę na przygotowanie rodziców do jej pełnienia. $\mathrm{Z}$ omawianego badania wynika, że im lepiej rodzice czują się przygotowani do realizacji tego zadania, tym częściej je świadomie podejmują. $Z$ drugiej zaś strony, w szerokim ujęciu wychowania seksualnego, niemal każde zachowanie rodziców, świadome i nieuświadomione, ma wydźwięk wychowawczy, nacechowany dodatnio lub ujemnie. Warto podjąć namysł, a za nim działania, w jaki sposób pomóc rodzicom w świadomym wypełnianiu ważnej roli wychowawców dzieci w kontekście ich seksualności i jak wesprzeć ich w budowaniu poczucia kompetencji w tym zakresie. Im bowiem silniejsze przekonanie o własnej kompetencji w zakresie wychowania seksualnego swoich dzieci, w przypadku badanych osób, tym częstsze rzeczywiste podejmowanie takiej aktywności.

Tabela 4. Zależność pomiędzy poczuciem kompetencii rodziców w kwestii wychowania seksualnego a jego realizacja w środowisku rodzinnym

\begin{tabular}{|l|c|c|c|c|c|c|}
\hline \multirow{2}{*}{$\begin{array}{l}\text { Poczucie kompetencii w zakresie } \\
\text { wychowania seksualnego } \\
\text { dzieci }\end{array}$} & \multicolumn{6}{|c|}{$\begin{array}{c}\text { Podejmowanie wychowania seksualnego swojego dziecka } \\
\text { w środowisku rodzinnym }\end{array}$} \\
\cline { 2 - 8 } & \multicolumn{2}{|c|}{ TAK } & \multicolumn{2}{c|}{ NIE } & \multicolumn{3}{c|}{ Trudno powiedzieć } \\
\cline { 2 - 7 } & N & $\%$ & N & $\%$ & N & $\%$ \\
\hline Zdecydowanie tak & 14 & 27,5 & 1 & 20,0 & 2 & 11,8 \\
\hline Tak & 29 & 56,9 & 1 & 20,0 & 7 & 41,2 \\
\hline Trudno powiedzieć & 5 & 9,8 & 1 & 20,0 & 5 & 29,4 \\
\hline Raczej nie & 0 & 0 & 2 & 40,0 & 3 & 17,6 \\
\hline Zdecydowanie nie & 3 & 5,9 & 0 & 0 & 0 & 0 \\
\hline
\end{tabular}

$X^{2}=22,031 ; d f=8 ; p<0,005$

Źródło: badania własne

Dokonując analizy odpowiedzi rodziców dotyczących tematów, na które rozmawiają ze swoimi dziećmi, można zaryzykować stwierdzenie, że mają one charakter bardziej instrumentalny niż relacyjny. Badani rodzice najczęściej rozmawiali ze swoimi dziećmi o zmianach w wyglądzie i zachowaniu związanych $\mathrm{z}$ dojrzewaniem $(68,8 \%)$, 
miesiączkowaniu/polucjach (64,9\%), zakochaniu i pierwszych związkach $(63,6 \%)$, o tym, skąd się biorą dzieci $(57,1 \%)$ oraz jak zabezpieczyć się przed nieplanowaną ciążą $(53,2 \%)$. Dane te przedstawia tabela $5 . \mathrm{Z}$ pięciu najczęściej podejmowanych tematów, tylko jeden dotyczy relacji osobowych. Odnotowano także, że matki istotnie częściej niż ojcowie podejmowały rozmowy dotyczące związku seksualności $z$ wartościami $(p=0,003)$ oraz tematu miesiączkowania i polucji $(p=0,013)$. Ponadto badane kobiety wykazywały nie w pełni istotną tendencję do podejmowania rozmów o zmianach w wyglądzie związanych $z$ dojrzewaniem $(\mathrm{p}=0,087)$ oraz na temat zakochania i pierwszych związków $(\mathrm{p}=0,086)$.

Tabela 5. Tematy, na które rodzice rozmawiają ze swoim dzieckiem

\begin{tabular}{|c|c|c|c|c|c|c|}
\hline \multirow{2}{*}{$\begin{array}{l}\text { Tematy rozmów rodziców } \\
\text { z dzieckiem }\end{array}$} & \multicolumn{2}{|c|}{ Cala grupa } & \multicolumn{2}{|c|}{ Kobiety } & \multicolumn{2}{|c|}{ Mężczyźni } \\
\hline & $\mathbf{N}$ & $\%$ & $\mathbf{N}$ & $\%$ & $\mathbf{N}$ & $\%$ \\
\hline $\begin{array}{l}\text { Zabezpieczenie przed niepla- } \\
\text { nowanq̨ ciqzżq }\end{array}$ & 41 & 53,2 & 35 & 51,5 & 6 & 54,5 \\
\hline $\begin{array}{l}\text { Zabezpieczenie przed cho- } \\
\text { robami przenoszonymi droga } \\
\text { płciowq }\end{array}$ & 38 & 39,4 & 33 & 50,0 & 5 & 45,5 \\
\hline Inicjacja seksualna & 25 & 32,5 & 23 & 34,8 & 2 & 18,2 \\
\hline Miesiq̨czka/polucje & 50 & 64,9 & 47 & 71,2 & 3 & 27,3 \\
\hline $\begin{array}{l}\text { Zmiany w wyglqadzie i zacho- } \\
\text { waniu, zwiqzane z dojrze- } \\
\text { waniem }\end{array}$ & 53 & 68,8 & 48 & 72,7 & 5 & 45,5 \\
\hline Zakochanie, pierwsze zwiqzki & 49 & 63,6 & 45 & 68,2 & 4 & 36,4 \\
\hline $\begin{array}{l}\text { Zwiqzek seksualności z war- } \\
\text { tościami (miłość, szacunek, } \\
\text { odpowiedzialność, wierność) }\end{array}$ & 40 & 51,9 & 39 & 59,1 & 1 & 9,1 \\
\hline Asertywność/presja seksualna & 17 & 22,1 & 15 & 22,7 & 2 & 18,2 \\
\hline Skqqd się biorq dzieci & 44 & 57,1 & 38 & 57,6 & 6 & 54,4 \\
\hline Pornografia & 19 & 24,7 & 16 & 24,2 & 3 & 27,3 \\
\hline Życie w małżeństwie i rodzinie & 29 & 37,7 & 27 & 40,9 & 2 & 18,2 \\
\hline $\begin{array}{l}\text { Wzorce/istota kobiecości/ } \\
\text { męskości }\end{array}$ & 26 & 33,8 & 24 & 36,4 & 2 & 18,2 \\
\hline $\begin{array}{l}\text { Emocje, rozwiqzywanie } \\
\text { konfliktów }\end{array}$ & 41 & 53,2 & 39 & 59,1 & 2 & 18,2 \\
\hline
\end{tabular}

Źródło: badania własne. 
Rodzice biorący udział w badaniu wyrażali również swoje opinie na temat celu wychowania seksualnego. Zauważa się, że respondenci doceniają $\mathrm{w}$ tym procesie i aspekt instrumentalny, związany z przekazywaniem wiedzy (np. nauka metod antykoncepcyjnych i naturalnego planowania rodziny), i formacyjny (np. powiązanie seksualności z wartościami takimi jaki odpowiedzialność, szacunek). Choć natężenie odpowiedzi dotyczących poszczególnych celów jest wyrównane, to jednak jako istotny cel wychowania seksualnego, badani rodzie wskazywali najczęściej naukę metod zapobiegania ciąży (średnia 4,65 ) oraz profilaktykę chorób przenoszonych drogą płciową (średnia 4,61). Na trzecim miejscu wskazywano powiązanie seksualności Z wartościami (średnia 4,60) oraz naukę odpierania presji seksualnej i asertywności (średnia 4,57). Najmniej istotnym celem (choć wciąż istotnym) dla badanych okazało się kształtowanie postaw tolerancji (średnia 4,22). Dane te przedstawia tabela 6 . W tym obszarze, podobnie jak miało to miejsce w przypadku tematów rozmów z dziećmi, dominuje podejście instrumentalne, choć obecne jest również relacyjne i ukierunkowane na formowanie odpowiedzialnych postaw dzieci wobec seksualności.

Tabela 6. Znaczenie poszczególnych celów wychowania

\begin{tabular}{|c|c|c|c|c|c|c|c|c|c|c|c|}
\hline \multirow{2}{*}{$\begin{array}{l}\text { Znaczenie } \\
\text { poszczególnych } \\
\text { celów wychowania }\end{array}$} & \multicolumn{2}{|c|}{ Ważne } & \multicolumn{2}{|c|}{$\begin{array}{l}\text { Raczej } \\
\text { ważne }\end{array}$} & \multicolumn{2}{|c|}{$\begin{array}{l}\text { Trudno } \\
\text { powie- } \\
\text { dzieć }\end{array}$} & \multicolumn{2}{|c|}{$\begin{array}{c}\text { Raczei } \\
\text { nieważne }\end{array}$} & \multicolumn{2}{|c|}{$\begin{array}{l}\text { Zdecy- } \\
\text { dowanie } \\
\text { nieważne }\end{array}$} & \multirow{2}{*}{$\begin{array}{l}\text { Średnia } \\
\text { (od } 1 \\
\text { do 5) }\end{array}$} \\
\hline & $\mathbf{N}$ & $\%$ & $\mathbf{N}$ & $\%$ & $\mathbf{N}$ & $\%$ & $\mathbf{N}$ & $\%$ & $\mathbf{N}$ & $\%$ & \\
\hline $\begin{array}{l}\text { Nauka metod anty- } \\
\text { koncepcyinych/natu- } \\
\text { ralnego planowania } \\
\text { rodziny }\end{array}$ & 59 & 78,7 & 11 & 14,7 & 4 & 5,3 & 0 & 0,0 & 1 & 1,3 & 4,69 \\
\hline $\begin{array}{l}\text { Profilaktyka chorób } \\
\text { przenoszonych drogq } \\
\text { płciowq }\end{array}$ & 50 & 67,6 & 21 & 28,4 & 2 & 2,7 & 0 & 0,0 & 1 & 1,4 & 4,61 \\
\hline $\begin{array}{l}\text { Nauka asertywności } \\
\text { /odpierania presji } \\
\text { seksualnej }\end{array}$ & 50 & 67,6 & 18 & 24,3 & 5 & 6,8 & 0 & 0,0 & 1 & 1,4 & 4,57 \\
\hline $\begin{array}{l}\text { Przygotowanie do } \\
\text { życia w rodzinie } \\
\text { i matżeństwie }\end{array}$ & 45 & 58,4 & 24 & 31,2 & 6 & 7,8 & 0 & 0,0 & 2 & 2,6 & 4,43 \\
\hline
\end{tabular}




\begin{tabular}{|c|c|c|c|c|c|c|c|c|c|c|c|}
\hline \multirow{2}{*}{$\begin{array}{l}\text { Znaczenie } \\
\text { poszczególnych } \\
\text { celów wychowania }\end{array}$} & \multicolumn{2}{|c|}{ Ważne } & \multicolumn{2}{|c|}{$\begin{array}{l}\text { Raczej } \\
\text { ważne }\end{array}$} & \multicolumn{2}{|c|}{$\begin{array}{l}\text { Trudno } \\
\text { powie- } \\
\text { dzieć }\end{array}$} & \multicolumn{2}{|c|}{$\begin{array}{c}\text { Raczej } \\
\text { nieważne }\end{array}$} & \multicolumn{2}{|c|}{$\begin{array}{l}\text { Zdecy- } \\
\text { dowanie } \\
\text { nieważne }\end{array}$} & \multirow{2}{*}{$\begin{array}{l}\text { Średnia } \\
\text { (od } 1 \\
\text { do 5) }\end{array}$} \\
\hline & $\mathbf{N}$ & $\%$ & $\mathbf{N}$ & $\%$ & $\mathbf{N}$ & $\%$ & $\mathbf{N}$ & $\%$ & $\mathbf{N}$ & $\%$ & \\
\hline $\begin{array}{l}\text { Profilaktyka ryzy- } \\
\text { kownych zachowań } \\
\text { seksualnych }\end{array}$ & 41 & 53,9 & 27 & 35,5 & 5 & 6,6 & 2 & 2,6 & 1 & 1,3 & 4,38 \\
\hline $\begin{array}{l}\text { Pomoc w osiqganiu } \\
\text { dojrzałości psycho- } \\
\text { seksualnej }\end{array}$ & 43 & 55,8 & 21 & 27,3 & 10 & 13,0 & 2 & 2,6 & 1 & 1,3 & 4,34 \\
\hline $\begin{array}{l}\text { Pomoc w zintegro- } \\
\text { waniu seksualności ze } \\
\text { wszystkimi sferami } \\
\text { życia (np. duchowq } \\
\text { emocjonalnq) }\end{array}$ & 35 & 45,5 & 28 & 36,4 & 13 & 16,9 & 0 & 0,0 & 1 & 1,3 & 4,25 \\
\hline $\begin{array}{l}\text { Wsparcie w rozwoju } \\
\text { tożsamości psycho- } \\
\text { seksualnej }\end{array}$ & 32 & 42,1 & 32 & 42,1 & 11 & 14,5 & 0 & 0,0 & 1 & 1,3 & 4,24 \\
\hline $\begin{array}{l}\text { Powiqzanie seksualno- } \\
\text { ści z wartościami (np. } \\
\text { odpowiedzialnościq } \\
\text { miłościq, szacunkiem) }\end{array}$ & 50 & 66,7 & 22 & 29,3 & 2 & 2,7 & 0 & 0,0 & 1 & 1,3 & 4,60 \\
\hline $\begin{array}{l}\text { Kształtowanie } \\
\text { postaw tolerancii } \\
\text { (np. dla osób homo- } \\
\text { seksualnych) }\end{array}$ & 34 & 50,7 & 16 & 23,9 & 16 & 23,9 & 0 & 0,0 & 1 & 1,5 & 4,22 \\
\hline Inne & 2 & 50,0 & 0 & 0,0 & 1 & 25,0 & 0 & 0,0 & 1 & 25,0 & 3,50 \\
\hline
\end{tabular}

Źródło: badania własne.

Tematy poruszane przez rodziców powiązane były z niektórymi celami wychowania seksualnego. Rodzice wyżej wartościujący naukę metod antykoncepcji i planowania rodziny częściej poruszali w rozmowach $\mathrm{z}$ dziećmi takie kwestie wychowawcze, jak miesiączkowanie/ polucje $\left[\mathrm{X}^{2}(4)=10,578 ; \mathrm{p}=0,014\right]$ oraz zakochanie/pierwsze związki $\left[X^{2}(3)=9,188 ; p=0,027\right]$. Przygotowanie do życia w małżeństwie i rodzinie powiązane było $z$ tematem zabezpieczenia przed nieplanowaną ciążą $\left[X^{2}(3)=8,578 ; p=0,035\right]$ oraz życia w małżeństwie i rodzinie $\left[\mathrm{X}^{2}(3)=7,809 ; \mathrm{p}=0,050\right]$, pomoc w osiąganiu dojrzałości psychoseksualnej z tematyką zmian w wyglądzie i zachowaniu $\left[\mathrm{X}^{2}(4)=10,114\right.$; $\mathrm{p}=0,039]$ oraz zakochania i pierwszych związków $\left[\mathrm{X}^{2}(4)=14,544\right.$; $\mathrm{p}=0,006]$. 
Nieco ponad jedna trzecia badanych rodziców zadeklarowała, że nie odczuwa żadnych trudności w procesie wychowania seksualnego swoich dzieci (36,4\%). Rodzice, którzy doświadczają przeszkód $(63,6 \%)$, najczęściej wskazywali, że są to: niechęć dziecka do prowadzenia rozmów o seksualności z rodzicami $(37,7 \%)$, niewiedza, czego dziecko aktualnie potrzebuje (20,8\%), brak pomysłu, jak zacząć lub poprowadzić taką rozmowę $(18,2 \%)$ oraz towarzyszące rodzicowi poczucie skrępowania podczas rozmów o seksualności (15,6\%). Dane te zostały przedstawione w tabeli 7 . Warto zaznaczyć, że jednocześnie większość rodziców na pytanie o to, czy sądzą, że ich dziecko chce swobodnie rozmawiać $\mathrm{z}$ rodzicami o seksualności odpowiedziała twierdząco (65\%). Wydaje się, że możliwym sposobem na uniknięcie w przyszłości lub aktualne rozwiązanie najczęściej wskazywanych przez respondentów problemów - odczuwanej niechęci dziecka i niewiedzy co do jego potrzeb - jest nawiązanie bliższej z nim relacji. O ile przeszkody takie, jak brak wiedzy lub czasu na spokojną rozmowę można w stosunkowo prosty, instrumentalny sposób usunąć, o tyle przeszkody o charakterze relacyjnym, takie jak odczuwana niechęć dziecka, wymagają czasu i osobistego zaangażowania rodzica w celu ich zmniejszenia lub całkowitego wyeliminowania. Stanowią ono jednocześnie niejako dowód na to, jak silnie wychowanie seksualne w rodzinie powiązane jest $\mathrm{z}$ jakością relacji wewnątrzrodzinnych.

Tabela 7. Trudności doświadczane przez rodziców w procesie wychowania seksualnego dziecka

\begin{tabular}{|l|c|c|c|c|}
\hline \multirow{2}{*}{$\begin{array}{l}\text { Trudności doświadczane przez } \\
\text { rodziców w procesie wychowania } \\
\text { seksualnego dziecka }\end{array}$} & $\mathbf{2}$ & $\%$ & $\mathbf{2}$ & $\%$ \\
\cline { 2 - 5 } & $\mathbf{N}$ & 15,6 & 65 & 84,4 \\
\hline $\begin{array}{l}\text { Skrępowanie w rozmowach z dzie- } \\
\text { ckiem o seksie/seksualności }\end{array}$ & 12 & 37,7 & 48 & 62,3 \\
\hline $\begin{array}{l}\text { Niechęć dziecka do rozmawiania } \\
\text { z rodzicami o seksie/seksualności }\end{array}$ & 29 & 11,7 & 68 & 88,3 \\
\hline $\begin{array}{l}\text { Obawa, że nie będę znać odpowie- } \\
\text { dzi na pytania dziecka }\end{array}$ & 9 & 10,4 & 69 & 89,6 \\
\hline $\begin{array}{l}\text { Brak czasu na spokojnq rozmowę } \\
\text { z dzieckiem }\end{array}$ & 8 & 18,2 & 63 & 81,8 \\
\hline $\begin{array}{l}\text { Brak pomysłu jak zaczqć/przeprowa- } \\
\text { dzić rozmowę z dzieckiem }\end{array}$ & 14 & 11,7 & 68 & 88,3 \\
\hline $\begin{array}{l}\text { Natłok innych, ważniejszych kwestii } \\
\text { wychowawczych }\end{array}$ & 9 & & 68 \\
\hline
\end{tabular}




\begin{tabular}{|c|c|c|c|c|}
\hline \multirow{2}{*}{$\begin{array}{l}\text { Trudności doświadczane przez } \\
\text { rodziców w procesie wychowania } \\
\text { seksualnego dziecka }\end{array}$} & \multicolumn{2}{|c|}{ TAK } & \multicolumn{2}{|c|}{ NIE } \\
\hline & $\mathbf{N}$ & $\%$ & $\mathbf{N}$ & $\%$ \\
\hline $\begin{array}{l}\text { Kłopoty w relacii ze współmałżonkiem } \\
\text { / niezadowolenie z jakości } \\
\text { małżeństwa }\end{array}$ & 3 & 3,9 & 74 & 96,1 \\
\hline $\begin{array}{l}\text { Niewiedza, czego teraz moje dziecko } \\
\text { potrzebuje w tym temacie }\end{array}$ & 16 & 20,8 & 61 & 79,2 \\
\hline $\begin{array}{l}\text { Obawa, że jest już za późno na } \\
\text { rozpoczęcie takich rozmów }\end{array}$ & 5 & 6,5 & 72 & 93,5 \\
\hline $\begin{array}{l}\text { Obawa, że jest za wcześnie na } \\
\text { rozpoczęcie takich rozmów }\end{array}$ & 3 & 3,9 & 74 & 96,1 \\
\hline Nie odczuwam żadnych trudności & 28 & 36,4 & 49 & 63,6 \\
\hline
\end{tabular}

Źródło: badania własne.

Rodzice, którzy wzięli udział w badaniu, największe zagrożenie dla rozwoju seksualnego młodzieży widzieli w korzystaniu przez nią z narkotyków i alkoholu (średnia 4,46), pornografii (średnia 4,32), w chaosie aksjonormatywnym współczesnego świata (średnia 4,29), braku czasu dla rodziny (średnia 4,27) oraz prostytucji (średnia 4,19). Najmniejsze obawy rodziców budziły łatwość dostępu do środków antykoncepcyjnych (średnia 3,09) oraz malejące znaczenie Kościoła w kwestiach wychowania (średnia 3,07). Dane te przedstawiono w tabeli 8. Rodzice potencjalnie mają wiele narzędzi przeciwdziałania niekorzystnemu wpływowi wskazanych zjawisk na życie ich dzieci. Wiele badań empirycznych dowodzi, że od jakości wychowania w rodzinie zależy podatność młodzieży na niekorzystne czynniki środowiskowe czy kulturowe (np. spożywanie alkoholu czy wybieranie wartości utylitarystycznych). Jakość życia rodzinnego w tym kontekście przejawia się w zaspokojeniu potrzeb dziecka - miłości, bezpieczeństwa, akceptacji, przynależności, budowaniu zaufania w relacji rodzice-dziecko, wspólnym spędzaniu czasu czy niedyrektywnych rozmowach. Ponadto, wyłonione w tym badaniu i innych podobnych, obszary zagrażające harmonijnemu rozwojowi seksualnemu młodzieży, mogą stać się elementami działań profilaktycznych skierowanych do adolescentów oraz szkoleniowych, skierowanych do ich rodziców.

W omawianym badaniu 81,8\% rodziców uznało, że pornografia stanowi źródło zagrożenia dla rozwoju seksualnego ich dzieci, jednak tylko $24,7 \% \mathrm{z}$ nich podjęło ze swoim dzieckiem rozmowę na 
jej temat. Brak czasu dla rodziny jako zagrożenie w tym kontekście wskazało $84,5 \%$ badanych, natomiast rozmowy na temat życia rodzinnego i małżeńskiego podjęło tylko 37,7\% badanych rodziców. Te przykłady pozwalają przypuszczać, że rodzice dostrzegają określone zagrożenia związane $\mathrm{z}$ wychowaniem seksualnym, ale $\mathrm{w}$ praktyce codziennego życia nie podejmują rozmów na ich temat $\mathrm{z}$ dziećmi.

Tabela 8. Zjawiska będq̨ce zagrożeniem w opinii rodziców dla harmonijnego rozwoju seksualnego młodzieży

\begin{tabular}{|c|c|c|c|c|c|c|c|c|c|c|c|}
\hline \multirow{2}{*}{$\begin{array}{l}\text { Zjawiska będqqce } \\
\text { zagrożeniem dla } \\
\text { harmonijnego } \\
\text { rozwoju seksual- } \\
\text { nego młodzieży }\end{array}$} & \multicolumn{2}{|c|}{$\begin{array}{l}\text { Zdecydo- } \\
\text { wanie tak }\end{array}$} & \multicolumn{2}{|c|}{ Raczej tak } & \multicolumn{2}{|c|}{$\begin{array}{l}\text { Trudno po- } \\
\text { wiedzieć }\end{array}$} & \multicolumn{2}{|c|}{ Raczej nie } & \multicolumn{2}{|c|}{$\begin{array}{l}\text { Zdecydo- } \\
\text { wanie nie }\end{array}$} & \multirow{2}{*}{$\begin{array}{l}\text { Średnia } \\
\text { (od } 1 \\
\text { do 5) }\end{array}$} \\
\hline & $\mathbf{N}$ & $\%$ & $\mathbf{N}$ & $\%$ & $\mathbf{N}$ & $\%$ & $\mathbf{N}$ & $\%$ & $\mathbf{N}$ & $\%$ & \\
\hline Pornografia & 45 & 58,4 & 18 & 23,4 & 8 & 10,4 & 6 & 7,8 & 0 & 0 & 4,32 \\
\hline Prostytucja & 40 & 51,9 & 19 & 24,7 & 12 & 15,6 & 5 & 6,5 & 1 & 1,3 & 4,19 \\
\hline Kultura popularna & 27 & 35,5 & 21 & 27,6 & 18 & 23,7 & 7 & 9,2 & 3 & 3,9 & 3,82 \\
\hline $\begin{array}{l}\text { Kultura } \\
\text { konsumpcyina }\end{array}$ & 20 & 27,4 & 24 & 32,9 & 20 & 27,4 & 7 & 9,6 & 2 & 2,7 & 3,73 \\
\hline $\begin{array}{l}\text { Korzystanie z nar- } \\
\text { kotyków, dopala- } \\
\text { czy, alkoholu itp. }\end{array}$ & 49 & 64,5 & 16 & 21,1 & 9 & 11,8 & 1 & 1,3 & 1 & 1,3 & 4,46 \\
\hline $\begin{array}{l}\text { Brak czasu dla } \\
\text { rodziny }\end{array}$ & 36 & 46,8 & 29 & 37,7 & 10 & 13,0 & 1 & 1,3 & 1 & 1,3 & 4,27 \\
\hline $\begin{array}{l}\text { Wyraźna obecność } \\
\text { seksualności w życiu } \\
\text { młodzieży }\end{array}$ & 31 & 41,3 & 23 & 20,7 & 17 & 22,7 & 4 & 5,3 & 0 & 0 & 4,08 \\
\hline $\begin{array}{l}\text { Chaos w świecie } \\
\text { wartości młodzieży }\end{array}$ & 38 & 50,7 & 24 & 32,0 & 10 & 13,3 & 3 & 4,0 & 0 & 0 & 4,29 \\
\hline $\begin{array}{l}\text { Zmiana patriar- } \\
\text { chalnego modelu } \\
\text { rodziny }\end{array}$ & 19 & 25,7 & 14 & 18,9 & 23 & 31,1 & 12 & 16,2 & 6 & 8,1 & 3,38 \\
\hline $\begin{array}{l}\text { Łatwa dostępność } \\
\text { do środków anty- } \\
\text { koncepcyjnych }\end{array}$ & 14 & 18,9 & 15 & 20,3 & 20 & 27,0 & 14 & 18,9 & 11 & 14,9 & 3,09 \\
\hline $\begin{array}{l}\text { Malejace znaczenie } \\
\text { Kościoła w kwestii } \\
\text { wychowania }\end{array}$ & 15 & 20,3 & 13 & 17,6 & 20 & 27,0 & 14 & 18,9 & 12 & 16,2 & 3,07 \\
\hline $\begin{array}{l}\text { Obecny sposób } \\
\text { realizacji WDŻ }\end{array}$ & 17 & 23,6 & 8 & 11,1 & 29 & 40,3 & 12 & 16,7 & 6 & 8,3 & 3,25 \\
\hline
\end{tabular}

Źródło: badania własne. 
Wobec rozpoznanego stanu wychowania seksualnego w rodzinie na podstawie niniejszych badań, badań innych autorów i literatury przedmiotu, wydaje się zasadne zaoferowanie profesjonalnego wsparcia rodzicom $\mathrm{w}$ realizacji tego procesu. $\mathrm{Na}$ pytanie, co mogłoby pomóc respondentom w realizacji wychowania seksualnego w rodzinie, rodzice najczęściej wskazywali, że wsparcie małżonka $(59,7 \%)$, w dalszej kolejności wsparcie pedagoga i psychologa szkolnego $(35,1 \%)$ oraz uczestnictwo dziecka w zajęciach $\mathrm{z}$ wychowania do życia w rodzinie $(28,6 \%)$. Na udział w warsztatach/spotkaniach dla rodziców oraz fachową literaturę jako potrzebne źródła wsparcia wskazała jedna piąta badanych (odpowiednio 26\% i 23,4\%). Dane te przedstawione są w tabeli 9. Zdecydowana przewaga wskazań na wsparcie małżonka jako preferowaną formę pomocy w procesie wychowania seksualnego wskazuje na to, jak dużą rolę odgrywają wewnątrzrodzinne relacje, nie tylko dla dzieci, ale także dla rodziców. Nowoczesne formy wsparcia, takie jak internetowe szkolenia dla rodziców czy grupy wsparcia, badani respondenci ocenili jako mało użyteczne.

Tabela 9. Preferowane formy wsparcia rodziców w realizacji wychowania seksualnego w rodzinie

\begin{tabular}{|c|c|c|c|c|}
\hline \multirow{2}{*}{$\begin{array}{l}\text { Preferowane formy wsparcia rodziców } \\
\text { w realizacii wychowania do życia } \\
\text { w rodzinie }\end{array}$} & \multicolumn{2}{|c|}{ TAK } & \multicolumn{2}{|c|}{ NIE } \\
\hline & $\mathbf{N}$ & $\%$ & $\mathbf{N}$ & $\%$ \\
\hline Wsparcie małżonka & 46 & 59,7 & 31 & 40,3 \\
\hline Wsparcie pedagoga / psychologa szkolnego & 27 & 35,1 & 50 & 64,9 \\
\hline $\begin{array}{l}\text { Udział w warsztatach / spotkaniach dla } \\
\text { rodziców }\end{array}$ & 18 & 23,4 & 59 & 76,6 \\
\hline $\begin{array}{l}\text { Literatura dla rodziców nt. wychowania } \\
\text { seksualnego młodzieży }\end{array}$ & 20 & 26,0 & 57 & 74,0 \\
\hline Internetowe grupy wsparcia & 2 & 2,6 & 75 & 97,4 \\
\hline Wsparcie księdza / osoby duchownej & 2 & 2,6 & 75 & 97,4 \\
\hline Internetowe szkolenia dla rodziców & 7 & 9,1 & 70 & 90,9 \\
\hline Uczestnictwo dziecka w lekcjach WDŻ & 22 & 28,6 & 55 & 71,4 \\
\hline
\end{tabular}

Źródło: badania własne. 


\section{Podsumowanie}

Przyjmuje się, że w przeprowadzonych badaniach osiągnięto założony ich cel, rozpoznano stosunek badanych rodziców wobec wychowania seksualnego ich dzieci. W odniesieniu do poznania aktywności wychowawczej rodziców, zdecydowana większość z nich realizuje wychowanie seksualne swoich dzieci. Ma to miejsce tym częściej, im bardziej rodzice czują się kompetentni w tym zakresie oraz im silniej doceniają znaczenie rodziny w wychowaniu seksualnym dzieci. Wskazane zależności w badanej grupie mają silny charakter. Ponadto odnotowano, że badani rozumieją proces wychowania seksualnego szeroko, dostrzegając, że wiele sytuacji codziennego życia, takich jak sposób odnoszenia się do siebie rodziców czy wartości pielęgnowane $\mathrm{w}$ rodzinie, pozostaje nieobojętne dla wychowania seksualnego ich dzieci. Niemniej jednak tematyka rozmów rodziców z dziećmi ma charakter bardziej instrumentalny niż relacyjny. Podobnie jest w przypadku celów wychowania seksualnego, które badani rodzice ocenili najwyżej. Są obecne w obu tych przypadkach aspekty relacyjne, jednak na pierwszy plan wysuwają się te o charakterze instrumentalnym.

W przypadku trudności, których doświadczają rodzice adolescentów, w badanej grupie najczęściej wskazywali oni, że jest to niechęć młodzieży do rozmów $\mathrm{z}$ rodzicami, niewiedza, czego aktualnie dziecko w tym zakresie potrzebuje i brak pomysłu, jak taką rozmowę poprowadzić. Wydaje się, że jedną, z zapewne wielu, możliwości zmniejszenia tych trudności jest nawiązanie bliższej osobowej relacji z dzieckiem. Sposób osiągnięcia tego celu wymaga szczegółowych rozstrzygnięć i wykracza poza ramy niniejszego przedłożenia. W tym miejscu po raz kolejny uwidacznia się znaczenie jakości wewnątrzrodzinnych relacji dla przebiegu procesu wychowania seksualnego.

Wśród zagrożeń dla wychowania seksualnego, które najsilniej dostrzegają badani rodzice, znalazły się zażywanie narkotyków i alkoholu, pornografia, chaos aksjonormatywny, w którym funkcjonuje młodzież. Niewątpliwie są to realne zagrożenia dla harmonijnego rozwoju seksualnego młodzieży. Warto, aby młodzież była objęta w tym zakresie działaniami profilaktycznymi. Być może pomocne okazałoby się wsparcie rodziców w tym kontekście. Przemawia za tym fakt, że mimo iż badani rodzice dostrzegają takie właśnie zagrożenia, to 
nie podejmują ze swoimi dziećmi rozmów na ich temat. J. Mastalski wskazuje, że jednym z zaniedbanych, a potrzebnych dziś paradygmatów formacyjnych nastolatka jest paradygmat detoksykacyjny. Rola rodzica polega w nim na uwrażliwianiu wychowanka na zagrożenia, przestrzeganiu przed skutkami ryzykownych zachowań i zachęcaniu do aktywności profilaktycznej ${ }^{29}$.

Badani rodzice zdecydowanie najczęściej wskazywali, że w procesie wychowania seksualnego dzieci pomogłoby im wsparcie współmałżonka. Nieco rzadziej oczekują wsparcia ze strony pedagoga i psychologa szkolnego. Najmniejszym zainteresowaniem badanych rodziców cieszą się innowacyjne formy wsparcia, takie jak szkolenia internetowe.

Uzyskane wyniki badań, z zaznaczonym w części metodologicznej zastrzeżeniem dotyczącym niemożności uogólnienia wyników badań ze względu na mało liczną grupę respondentów, w szczególności mężczyzn, potwierdzają tezę o istotnym znaczeniu rodziny w wychowaniu seksualnym młodzieży. Przyczynkowe badania wskazują na dalsze perspektywy badawcze, które mogą służyć celom poznawczym i praktycznym. $Z$ pewnością zasadnym jest rozszerzenie badań na reprezentatywną grupę respondentów. Dotychczasowe rezultaty badawcze pozwalają przyjmować, że relacje wewnątrzrodzinne mają istotne znaczenie dla procesu wychowania seksualnego w rodzinie, tak dla poszczególnych jego podmiotów, jak i jego przebiegu. Ich szczegółowa analiza, szczególnie wtedy, gdy w badaniu wzięliby udział jednocześnie rodzice i ich dzieci, może przynieść wiele istotnych z pedagogicznego punktu widzenia wniosków.

\section{Bibliografia}

Bee H., Psychologia rozwoju cztowieka, przeł. A. Wojciechowski, Zysk i S-ka, Poznań 2004.

Bołoz W., Promocja osoby w rodzinie, Wydawnictwo ATK, Warszawa 1998. Górska L., Podmiot i podmiotorwość w wychowaniu. Studium w perspektywie poznawczej pedagogiki integralnej, Wydawnictwo Naukowe Uniwersytetu Szczecińskiego, Szczecin 2008.

29 Por. J. Mastalski, Zaniedbane paradygmaty formacyjne nastolatka, dz. cyt., s. $110-111$. 
Jundziłł E., Rola prawidtowo zaspokojonej potrzeby mitości w życiu dorostego człowieka, w: Mitość i seks w percepcji uczniów, red. R. Pawłowska, E. Jundziłł, Wydawnictwo Uczelniane Bałtyckiej Wyższej Szkoły Humanistycznej, Koszalin 1999, s. 75-102.

Jundziłł E., Środowiskowe uwarunkowania ksztattowania sie postaw mtodzie$\dot{z} y$ wobec seksu, w: Mitośc $i$ seks w percepcji uczniów, red. R. Pawłowska, E. Jundziłł, Wydawnictwo Uczelniane Bałtyckiej Wyższej Szkoły Humanistycznej, Koszalin 1999, s. 103-140.

Juul J., Twoja kompetentna rodzina, przeł. D. Syska, Wydawnictwo MiND, Podkowa Leśna 2007.

Kempińska U., Matżeństwa mtodocianych. Ciqża, ślub i co dalej...? Wydawnictwo Edukacyjne Akapit, Torun 2012.

Kołodziej B., Rola rodziny w ksztattowaniu postawy wobec życia jako fundamentalnej wartości, w: Rodzina: źródto życia i szkota mitości, red. D. Kornas-Biela, Towarzystwo Naukowe KUL, Lublin 2001, s. 231-252.

Kurzępa J., Zagrożona niewinność. Zaktócenia rozwoju seksualności wspótczesnej młodzieży, Oficyna Wydawnicza Impuls, Kraków 2007.

Laphimon M., A Glossary of Term In Gender and Sexuality, The Rockefeller Foundation, Seul 2005, za: Z. Lew-Starowicz, Seksuologia psychospoteczna, w: Podstawy seksuologii, red. Z. Lew-Starowicz, V. Skrzypulec, Wydawnictwo Lekarskie PZWL, Warszawa 2010, s. 25-67.

Lew-Starowicz Z., Encyklopedia erotyki, Muza, Warszawa 2004.

Lew-Starowicz Z., Seks partnerski, Wydawnictwo Lekarskie PZWL, Warszawa 1983.

Lew-Starowicz Z., Seksuologia sq̨dowa, Wydawnictwo Lekarskie PZWL, Warszawa 2000.

Mastalski J., Zaniedbane paradygmaty formacyjne nastolatka, „Studia Pedagogica Ignatiana” 2017, t. 20, nr 2, s. 103-118.

Mazan A., Metody integracji w wychowaniu rodzinnym, w: Rodzina przestrzeniq rozwoju osoby. Perspektywa pedagogiczna, red. M. Jeziorański, D. Opozda, A. Rynio, Towarzystwo Naukowe KUL, Lublin 2012, s. $129-138$.

Obuchowska I., Psychologiczne aspekty dojrzewania, w: Dojrzewanie, red. A. Jaczewski, B. Woynarowska, WSiP, Warszawa 1982, s. 131-206.

Obuchowska I., Jaczewski A., Rozwój erotyczny, Żak, Warszawa 2002.

Oleszkowicz A., Senejko A., Dorastanie, w: Psychologia rozwoju cztowieka, red. J. Trempała, PWN, Warszawa 2001, s. 163-201.

Półtawska W., Rola rodziców w wychowaniu seksualnym mtodzieży, w: Wychowanie w rodzinie, red. F. Adamski, Wydawnictwo Petrus, Kraków 2010, s. 193-208.

Rojewska E., Personalistyczna orientacja wychowawcza rodziców a integracja seksualna mtodzieży. Badania empiryczne, niepublikowana rozprawa doktorska napisana pod kierunkiem prof. dra hab. Zdzisława Kroplewskiego, Szczecin 2015, s. 119-120. 
Ryś M., Poziom zaspokojenia potrzeb w dziecinstwie a zaspokojenie potrzeb w matzeństwie, „Problemy Rodziny” 1993, nr 1, s. 20-24.

Szlendak T., Supermarketyzacja. Religia i obyczaje seksualne mtodzieży w kulturze popularnej, Wydawnictwo Uniwersytetu Wrocławskiego, Wrocław 2008.

Tyszka Z., Socjologia rodziny a pedagogika rodziny. Przedmiot badań - możliwości wspótdziatania badawczego, „Roczniki Socjologii Rodziny” 1998, t. 10, s. 77-90.

Waszyńska K., Zielona-Jenek M., Zjawisko seksualizacji jako wyzwanie dla wspótczesnej edukacji, „Studia Edukacyjne” 2016, nr 39, s. 351-375.

Włodarczyk R., Żłobicki W., Wstęp, w: Interdyscyplinarnośc $i$ transdyscyplinarność pedagogiki - wymiary teoretyczny i praktyczny, red. R. Włodarczyk, W. Żłobicki, Oficyna Wydawnicza Impuls, Kraków 2011, s. 9-10.

\section{ADRES DO KORESPONDENCJI}

Dr Ewa Rojewska

Uniwersytet Szczeciński

Wydział Teologiczny

e-mail: ewa.rojewska@usz.edu.pl 